\title{
MEASURING THE IMPACTS OF REPRESENTATION IN Legal AID AND COMMUNiTy Legal SERVICES SETTINGS: CONSIDERATIONS FOR CANADIAN RESEARCH
}

\author{
SARAH BUHLER ${ }^{*}$ AND MiChELle C. KORPAN**
}

\begin{abstract}
There is currently a gap in Canadian empirical research examining the impacts of legal representation in legal aid and clinic settings. This article advocates for addressing the research gap and suggests how such research could be pursued. Empirical data is crucial to making the case for ongoing investments in publicly funded legal assistance and to ensuring the effectiveness of such assistance. Yet current research, mainly from American studies, tends to focus narrowly on litigation outcomes. This leaves many aspects of the impact of legal representation unclear, particularly regarding service delivery for vulnerable and marginalized clients. Research must examine clients' own experiences and perspectives of legal processes so as to better reflect the complex relationship between legal representation and justice.
\end{abstract}

\section{TABLE OF CONTENTS}

I. INTRODUCTION ............................... 1117

II. WHY STUDY THE IMPACTS OF LEGAL REPRESENTATION

In Legal Aid AND COMMUNITY Legal SERVICES ConteXts? . . . . . . 1119

III. THE EXISTING RESEARCH ON THE IMPACTS OF LEGAL REPRESENTATION: A FocUS ON ADJUDICATION OUTCOMES $\ldots \ldots \ldots 1121$

IV. CONSIDERATIONS FOR CANADIAN RESEARCH ON THE IMPACTS OF LEGAL REPRESENTATION . . . . . . . . . . . . . . . 1127

A. IMPACTS OF THE LAWYER-CliENT RELATIONSHIP . . . . . . . . 1128

B. IMPACTS OF INFORMAL LEGAL ADVOCACY . . . . . . . . . . . . 1129

C. IMPACTS OF REPRESENTATION IN THE LITIGATION CONTEXT (BEYOND AdJUDICATION OUTCOMES) . . . . . . . . . . . 1130

D. A MORE NUANCED AND BRoAder View of "Outcomes" . . . . . . . . . . . . . . . . . 1131

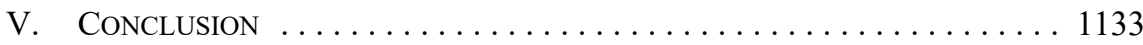

\section{INTRODUCTION}

Most advocates for access to justice in Canada would agree that increased access to legal representation for those who cannot afford to hire lawyers is a necessary and uncontroversial goal. There is a growing literature documenting the unaffordability of private legal services and the inadequacy of publicly funded legal assistance. ${ }^{1}$ In response, recent high-profile

Associate Professor, University of Saskatchewan College of Law.

JD (University of Saskatchewan College of Law); LLM Candidate (University of Cambridge). The authors would like to thank the anonymous reviewers for their very helpful feedback.

1 See e.g. Canada, Department of Justice, The Unmet Need for Criminal Legal Aid: A Summary of Research Results, by Ab Currie (Ottawa: DOJ, 2003), online: $<$ https://www.justice.gc.ca/eng/rp-pr/csjsjc/ccs-ajc/rr03 la9-rr03_aj9/rr03_la9.pdf>; Melina Buckley, "Moving Forward on Legal Aid: Research on Needs and Innovative Approaches" (Ottawa: Canadian Bar Association, 2010) at 45-50, online: $<$ delivery.canadianelectroniclibrary.ca/PDFDelivery.aspx?a=9f1dba8c-48a1-4cda-ba78-f261b517f $02 \mathrm{f} \& \mathrm{~b}=812 \mathrm{~b} 19 \mathrm{~d} 0-\mathrm{e} 5 \mathrm{ff}-4943-858 \mathrm{e}-\mathrm{e} 80 \mathrm{bfcb} 8 \mathrm{a} 479 \& \mathrm{i}=\mathrm{y}>$; Carol McEown, Civil Legal Needs Research Report, 2nd ed (Vancouver: Law Foundation of British Columbia, 2009), online: <https://www.law foundationbc.org/wp-content/uploads/Civil-Legal-Needs-Research-FINAL.pdf >; Julie Macfarlane, "The 
reports have called for increased investments in legal aid and other initiatives, including law school clinics and pro bono service coordination efforts, to increase access to legal representation. ${ }^{2}$ However, there is little Canadian research that specifically examines the impacts or effectiveness of legal representation and virtually none that investigates the impacts of representation in legal aid or community legal clinic settings. ${ }^{3}$ In an era of austerity budgets, cuts to legal aid spending, and access to justice initiatives that focus on self-help rather than representation, ${ }^{4}$ it is increasingly important to be able to show the value of legal representation in legal aid and clinic settings. Empirical research has an important role to play in this regard. ${ }^{5}$ As Jeanne Charn and Jeffrey Selbin have argued, "[i]f done well, research [in this context] can help us allocate scarce resources more effectively and make the case for greater investments. ${ }^{, 6}$ Furthermore, understanding the impacts of representation may help legal service providers in legal aid and community legal clinic settings improve their practice and respond more meaningfully to the communities that they serve. As Jane Aiken and Stephen Wizner write, "[o]ur work as lawyers improves the more we know about our effectiveness and the more our choices are evidence based."7

The purpose of this article is twofold: first, to make the case that there is a need for Canadian empirical research on the impacts of legal representation and specifically the impacts of legal representation in community legal services and legal aid settings and, second, to suggest some possible directions and considerations for such research. We introduce the existing (mostly American) research about the impacts of legal representation to assess what these studies tell us about the impact of lawyers and, more importantly, to assess what Canadian researchers can learn about the design of future research studies.

We show that the existing research establishes that legal representation matters, especially with respect to the representation of vulnerable or marginalized clients. For this reason, we agree with Russell Engler that "we must accept as a starting point that, particularly where basic human needs are at stake, vulnerable litigants on the wrong end of power imbalances should be presumed to need full representation by a skilled representative." ${ }^{8}$ We note, however, that because the existing research tends to focus on litigation outcomes, many

National Self-Represented Litigants Project: Identifying and Meeting the Needs of Self-Represented Litigants, Final Report" (May 2013), online: <https://representingyourselfcanada.com/wp-content/ uploads/2015/07/nsrlp-srl-research-study-final-report.pdf >; Action Committee on Access to Justice in Civil and Family Matters, "Access to Civil \& Family Justice: A Roadmap for Change," (Ottawa: Action Committee on Access to Justice in Civil and Family Matters, 2013), online: <https://www.cfcjfcjc.org/sites/default/files/docs/2013/AC Report English Final.pdf>.

See e.g. Buckley, ibid; Action Committee on Access to Civil and Family Matters, ibid.

Regarding legal aid, research has tended to focus on the extent to which these services meet the needs of the public in terms of their coverage. See e.g. Canada, Department of Justice, Study of the Legal Services Provided to Penitentiary Inmates by Legal Aid Plans and Clinics in Canada (Ottawa: DOJ, 2002), online: $<$ https://www.justice.gc.ca/eng/rp-pr/csj-sjc/ccs-ajc/rr03_la10-rr03_aj10/rr03_la10.pdf > . See Buckley, supra note 1 at 6.

For a discussion of the impact of legal aid cuts in the criminal justice system, see Jennifer Bond, "The Cost of Canada's Legal Aid Crisis: Breaching the Right to State-Funded Counsel Within a Reasonable Time" (2012) 59:1 Crim LQ 28; Buckley, ibid at 52.

6 Jeanne Charn \& Jeffrey Selbin, "The Clinic Lab Office” [2013] Wis L Rev 145 at 154.

Jane H Aiken \& Stephen Wizner, "Measuring Justice" [2013] Wis L Rev 79 at 79.

Russell Engler, "When Does Representation Matter?" in Samuel Estreicher \& Joy Radice, eds, Beyond Elite Law: Access to Civil Justice in America (New York: Cambridge University Press, 2016) 71 at 86 [Engler, "Representation"]. See also Marc Galanter, "Why the 'Haves' Come Out Ahead: Speculations on the Limits of Legal Change" (1974) 9:1 Law \& Soc'y Rev 95. Galanter's early research in the early 1970 s found that the ability to hire lawyers is an advantage held by those with resources and permits them to generally prevail against those without similar resources. 
aspects of legal representation's impact remain unclear. These features include how lawyers or other representatives impact their clients' perception of the fairness of legal proceedings, the impacts of lawyers on non-court-related matters, and the long-term and systemic impacts of legal representation.

In this article, we discuss why empirical data regarding the impacts of legal representation matters and why it particularly matters in legal aid and community legal services contexts. We then introduce existing studies that attempt to provide such data. ${ }^{9}$ As stated above, existing research on legal representation's impact tends to focus quite narrowly on win or loss litigation outcomes. We argue that while case outcomes are one way to evaluate the impact of legal representation, it is problematic to focus solely on litigation outcomes data. We propose that Canadian research should be informed by recognition of clients' experiences of legal processes, advocacy, and outcomes, as well as broader policy or systemic goals. Ultimately, we propose that researchers should attempt to gauge to what extent legal representation helps participants achieve impacts that are important to members of marginalized communities. This orientation will encourage research that captures the complexities of lawyer-client relationships, substantive and procedural justice, and the connections between legal representation and social justice. Crucially, it may also help legal service providers evaluate their approaches to practice to ensure they are working as meaningfully as possible with the clients and the communities they serve.

In this article, we focus on research questions relating to the impact of lawyers in legal aid and community legal services settings. Of course, central to any research project are fundamental questions relating to funding, ethics, and methodology; these issues are outside the scope of this present project. This article, however, could provide a starting point for analysis of these important and related issues.

\section{WHY STUDY THE IMPACTS OF LEGAL REPRESENTATION IN Legal AID AND Community Legal SERVICES ConTeXts?}

Legal aid and community legal service contexts warrant particular attention within legal representation research. By "legal aid and community legal services," we refer to publicly funded or non-profit legal service providers that seek to facilitate access to justice for people who are least able to afford private legal services. All provinces and territories in Canada have some system of publicly funded legal aid, although legal aid takes different forms depending on the jurisdiction. Jurisdictions such as Ontario have a well-established community clinic network as part of their legal aid system ${ }^{10}$; others, such as Saskatchewan, rely primarily on a staff model. ${ }^{11}$ Many jurisdictions employ a hybrid approach with a mix

9 The studies include: D James Greiner, Cassandra Wolos Pattanayak \& Jonathan Hennessy, "How Effective are Limited Legal Assistance Programs? A Randomized Experiment in a Massachusetts Housing Court" (2012), online: $<$ https://ssrn.com/abstract=1880078> ["Housing Court Study"]; D James Greiner, Cassandra Wolos Pattanayak \& Jonathan Hennessy, "The Limits of Unbundled Legal Assistance: A Randomized Study in a Massachusetts District Court and Prospects for the Future" (2013) 126:4 Harv L Rev 901 [“District Court Study"]; D James Greiner \& Cassandra Wolos Pattanayak, "Randomized Evaluation in Legal Assistance: What Difference Does Representation (Offer and Actual Use) Make?" (2012) 121:8 Yale LJ 2118 [“UI Study”].

10 See Legal Aid Ontario, “Historical Overview," online: $<$ https://www.legalaid.on.ca/en/about/historical overview.asp>.

11 See Legal Aid Saskatchewan, “About Us,” online: < https://www.legalaid.sk.ca/about/index.php>. 
of models, including certificate programs, where legal aid is provided by members of the private bar. ${ }^{12}$ Legal clinics exist in many provinces and may or may not be funded by the government. Some include reliance on pro bono lawyers. ${ }^{13}$ Many law schools also partner with or host clinics. ${ }^{14}$ What unites these often diverse organizations and models is their emphasis on providing legal services to members of marginalized communities - members of society most likely to be alienated from legal institutions, yet who are disproportionately impacted by legal problems and legal systems. ${ }^{15}$

Jeanne Charn and Jeffrey Selbin point out that "[e]mpirical claims have dominated debates about legal services since its inception, but they have rarely been tested. Since most of the important questions in the field cannot be resolved by normative debate, research is needed to fill the evidence gap." 16 The stakes are elevated for research on the impact of legal representation in contexts such as community legal clinics, law school clinics, and statefunded legal assistance programs like legal aid, because funders are interested in seeing "value" for their investments. We agree with Charn and Selbin that while legal service providers may believe strongly that their work has a positive impact, "evidence is likely to be even more powerful" when it comes to convincing funders to invest in these programs. ${ }^{17}$ As Clare Pastore points out, meaningful data can also potentially stave off concerns about state-funded counsel being unaffordable and therefore not worth the investment. ${ }^{18}$ Quite simply, data makes it easier for investment to occur. These concerns tied to economic downturns resonate in Canada, where a number of provincial governments are dealing with substantial deficits and determining how to allocate scarce funds. ${ }^{19}$ As a result, given the "growing demand for legal services and shrinking supply," Selbin, Charn, Anthony Alfieri and Stephen Wizner have said empirical research on legal service delivery "has become imperative." ${ }^{20}$ Designing ways to evaluate the impacts of work done in legal aid and community legal clinic settings that address the complexities and goals of work in these contexts is therefore an important endeavour.

For a recent overview of legal aid in Canada, see House of Commons, Standing Committee on Justice and Human Rights, Access to Justice Part 2: Legal Aid (October 2017) (Chair: Anthony Housefather), online: <publications.gc.ca/collections/collection_2017/parl/xc66-1/XC66-1-1-421-16-eng.pdf>. See e.g. Calgary Legal Guidance, "Volunteer," online: <clg.ab.ca/get-involved/volunteer/>; Pro Bono Law Saskatchewan, "Volunteer," online: <pblsask.ca/volunteer\#Get\%20Involved>. See Association for Canadian Clinical Legal Education, "Canadian Legal Clinics," online: <accle.ca/ links/>.

15 Ab Currie, "A National Survey of the Civil Justice Problems of Low- and Moderate-Income Canadians: Incidence and Patterns" (2006) 13:3 Intl J Leg Profession 217; Buckley, supra note 1 at 2-3, 40; Canada, Department of Justice, The Legal Problems of Everyday Life: The Nature, Extent and Consequences of Justiciable Problems Experienced by Canadians, by Ab Currie (Ottawa: DOJ, 2009) at 23, online: <www.justice.gc.ca/eng/rp-pr/csj-sjc/jsp-sjp/rr07 la1-rr07 aj1/rr07 la1.pdf> [Currie, Legal Problems]; Rebecca L Sandefur, "What We Know and Need to Know About the Legal Needs of the Public" (2016) 67:2 SCL Rev 443 at 446-47.

$16 \quad$ Supra note 6 at 154; see also Jeffrey Selbin et al, "Service Delivery, Resource Allocation, and Access to Justice: Greiner and Pattanayak and the Research Imperative" (2012) 122 Yale LJ Forum 45 at 46 ; Catherine R Albiston \& Rebecca L Sandefur, "Expanding the Empirical Study of Access to Justice" [2013] Wis L Rev 101.

$17 \quad$ Aiken \& Wizner, supra note 7 at 81.

18 Clare Pastore, "Gideon is My Co-Pilot: The Promise of Civil Right to Counsel Pilot Programs" (2014) 17:1 UDC L Rev 75 at 79.

19 See e.g. Jennifer Graham, "Premier Brad Wall Says Saskatchewan Deficit Has Climbed to \$1.2 Billion," The Globe and Mail (6 February 2017), online: <www.theglobeandmail.com/news/politics/premierbrad-wall-warns-saskatchewan-deficit-has-climbed-to-12-billion/article33911203/>. Selbin et al, supra note 16 at 46. 
In sum, empirical research in this setting has two primary purposes. First, it can provide information about how well existing services are working and where improvement is needed. This outcome relates to what Charn and Selbin refer to as the "demand side" of legal service delivery. ${ }^{21}$ Second, this empirical data can justify and guide the allocation of resources. It is thereby also relevant to decisions on the "supply side" of services. ${ }^{22}$ A program that is working well - however that is measured - is more likely to be regarded as worthy of financial and other investment. As we argue below, we believe these features call for context-sensitive research that takes account of the impacts of legal representation beyond adjudication outcomes.

\section{THE EXISTING RESEARCH ON THE IMPACTS OF LEGAL REPRESENTATION: A FOCUS ON ADJUDiCATION OUTCOMES}

There is currently a significant dearth of Canadian research on the impacts of legal representation. As noted by the Canadian Bar Association's Access to Justice Committee:

\footnotetext{
We know little [in Canada] about the relative effectiveness and efficiency of various service delivery models, legal information, assistance and representation ... and how to match processes and legal services to the nature and intensity of the legal dispute. At this time, we do know that we fall far behind the health and education systems in our commitment to and capacity for evidence-based decision making. ${ }^{23}$
}

There are a small number of Canadian studies that investigate people's satisfaction levels with their lawyers. For example, Ab Currie's research found that people who sought legal advice were generally satisfied with the assistance they received. ${ }^{24}$ Similarly, the Canadian Forum on Civil Justice also found that an overwhelming majority of people who sought various forms of legal advice for a legal problem found the assistance to be helpful, though this data encompassed legal advice obtained through a variety of means and not only through a lawyer. ${ }^{25}$ In a study of community legal services in Alberta, Joanne J. Paetsch and Lorne D. Bertrand found that most clients who received summary legal advice at Alberta community legal clinics were "extremely positive about the outcomes of their clinic experience," stating that they had a "better understanding of their legal rights and responsibilities, as well as their legal options and the pros and cons of those options." ${ }^{26}$ Most clients also reported they knew what to do next regarding their legal matter as a result of the advice they received. ${ }^{27}$ Similarly, Emily Paradis' important study of the Tenant Duty Counsel

Supra note 6 at 155 .

Ibid at 155 and throughout.

Access to Justice Committee, "Reaching Equal Justice Report: An Invitation to Envision and Act" (Ottawa: Canadian Bar Association, 2013) at 51, online: <https://www.cba.org/CBAMediaLibrary/ cba_na/images/Equal\%20Justice\%20-\%20Microsite/PDFs/EqualJusticeFinalReport-eng.pdf>. Currie, Legal Problems, supra note 15 at 65.

"Everyday Legal Problems and the Cost of Justice in Canada: Cost of Justice Survey Data" (Toronto: Canadian Forum on Civil Justice, 2018), online: <cfcj-fcjc.org/wp-content/uploads/Everyday-LegalProblems-and-the-Cost-of-Justice-in-Canada-Cost-of-Justice-Survey-Data.pdf $>$ [CFCJ, "Everyday Legal Problems: Cost"]. Of survey respondents who obtained legal advice to attempt to resolve their first serious civil or family justice problem, 33.4 percent found the advice "somewhat helpful" and 47 percent found it "very helpful." Of those who obtained legal advice for their second problem, 26.6 percent reported the advice was "somewhat helpful" and 55.8 percent found it "very helpful" (ibid at 131, 141).

26 Joanne J Paetsch \& Lorne D Betrand, "Summary Legal Advice Services in Alberta: Year 1 Results from the Community Legal Clinic Surveys," (Canadian Research Institute for Law and the Family, 2017), online: <www.crilf.ca/Documents/ALF\%20Clinics\%20Year\%201\%20-\%20Mar\%202017.pdf> at 51. Ibid at 18 . 
program in Ontario found that the majority of tenants surveyed were highly satisfied with the services received through the Tenant Duty Counsel program. ${ }^{28}$

These studies are important, but, with the exception of the Paradis study, they do not focus on the impact of representation itself or shed light on what actually happened in the clients' lives or legal matters as a result of the legal services they received. Paradis' extensive study of the Ontario Tenant Duty Counsel program examined outcomes related to the assistance provided through measures of impact beyond client satisfaction. The purpose of her study was (in part) "to provide quantitative and qualitative evidence on the effectiveness of the services offered by the Tenant Duty Counsel Program.." 29 Through surveys, interviews, and focus groups, Paradis examined the impact of advice and assistance provided through the program. We note that the Duty Counsel program mainly involves summary legal advice and very limited representation, so the study was not primarily concerned with the impacts of full legal representation. ${ }^{30}$ Indeed, Paradis also insightfully notes the complexity of determining whether an outcome can be defined as "successful" in housing law matters. Nonetheless, her study found that intervention by duty counsel "contributed to improved outcomes in 57 percent of cases overall, and there was an even higher success rate in specific case types: 60 percent success rates in arrears cases, at least 65 percent in eviction cases, and 71 percent success in extending tenants' repayment time." 31 The study's emphasis on qualitative data also shed light on some impacts beyond immediate case outcomes. For example, assistance through the program in some cases helped to "restore the landlord-tenant relationship" or was "very empowering for tenants, and [had] ripple effects into their community." 32 Assistance by duty counsel also impacted tenants' non-legal needs. ${ }^{33}$ As we will argue below, these kinds of varied and holistic impact measures are significant and should inform future research.

We were able to locate only one Canadian empirical study focusing specifically on the impacts of full representation by counsel on case outcomes: Sean Rehaag's important investigation of the role of lawyers in Canada's refugee determination system. ${ }^{34}$ Rehaag examined over 70,000 refugee decisions over a four-year time frame (2005-2009) with a view to examining whether refugee claimants represented by lawyers had a better chance of a positive decision as compared to claimants represented by non-lawyer advocates. His study showed that refugee claimants who were represented by lawyers had a significantly higher chance of a successful outcome in their matter as compared to those who were represented by non-lawyer consultants. Rehaag concludes that the key finding of his study is that "access to competent and qualified counsel — and especially to experienced lawyers — is a key determinant of outcomes in life-and-death refugee determinations." ${ }^{35}$

Emily Paradis, “Access to Justice: The Case for Ontario Tenants: Final Report of the Tenant Duty Counsel Review" (Advocacy Centre for Tenants Ontario, 2016) at 15, online: $<$ https://www.acto.ca/ production/wp-content/uploads/2017/07/TDCP_Report_2016.pdf > . Paradis looked at various other measures of the impact of representation; her research will be discussed further later in this article. Ibid at 24.

Ibid.

Ibid at 14.

Ibid at 65 .

Ibid at 68-69.

Sean Rehaag, "The Role of Counsel in Canada's Refugee Determinations System: An Empirical Assessment” (2011) 49:1 Osgoode Hall LJ 71.

Ibid at 93 . 
Although limited to the refugee determination process in Canada, Rehaag's study is consistent with much of the research on the impact of counsel on litigation outcomes in the American context. American research in this area demonstrates a wide array of legal forums and research methodologies. ${ }^{36}$ The most common research methodology involves "nonrandom observational studies of outcomes." ${ }^{37}$ This methodology typically involves an examination of case and file outcomes, where the researcher compares the results obtained by self-represented litigants with the results obtained by those represented by counsel. ${ }^{38}$ Researchers have also employed other methodologies, including observation of proceedings, qualitative interviews, surveys, and case studies. ${ }^{39}$ In addition, a small number of "randomized control" experiments have been undertaken in an attempt to eliminate the problem of selection bias, which refers to the concern that results of research might be skewed because "of the choices of lawyers, in selecting stronger cases, or of clients, in seeking out lawyers where their cases are stronger." 40

For the most part, the American research focuses, like Rehaag's study, on whether representation by lawyers affects the outcomes of formal adjudication processes; that is, whether people with lawyers are more likely to "win" their case than those who appear without counsel. Overwhelmingly, but with a few notable exceptions, the research indicates that legal representation does indeed make a difference in terms of adjudication outcomes. Indeed, scholars who have examined the body of research as a whole in order to generalize findings about lawyers' impact conclude that, overall, legal representation increases litigants' chances of adjudicative success. For example, Leslie Levin observes that the vast majority of existing studies suggest "individuals who are represented by lawyers obtain better outcomes in civil proceedings than those who are not." ${ }^{41}$ Levin cites a number of studies that indicate this appears to generally be so for people seeking immigration-related asylum, ${ }^{42}$ in social security disability appeals, ${ }^{43}$ in small claims court, ${ }^{44}$ and in cases before the Tax Court. ${ }^{45}$ Similarly, Emily S. Taylor Poppe and Jeffrey J. Rachlinski comprehensively review existing empirical research on the impact of legal representation in various civil law areas. ${ }^{46}$ The authors note that with few exceptions, "legal representation is associated with better

See Rebecca L Sandefur, "The Impact of Counsel: An Analysis of Empirical Evidence" (2010) 9:1 Seattle J for Social Justice 51 at 66-68 [Sandefur, "The Impact of Counsel"].

Leslie C Levin, "The Monopoly Myth and Other Tales about the Superiority of Lawyers" (2014) 82:6 Fordham L Rev 2611 at 2617.

See e.g. Russell Engler, "Connecting Self-Representation to Civil Gideon: What Existing Data Reveal About When Counsel Is Most Needed" (2010) 37:1 Fordham Urb LJ 37 [Engler, "Connecting SelfRepresentation"].

See Engler, "Representation," supra note 8 at 73.

Ibid.

Supra note 37 at 2617.

Ibid, citing Felinda Mottino, "Moving Forward: The Role of Legal Counsel in New York City Immigration Courts" (July 2000), online: < https://www.vera.org/publications/moving-forward-the-roleof-legal-counsel-in-new-york-city-immigration-courts>.

43 Levin, ibid, citing Herbert M Kritzer, Legal Advocacy: Lawyers and Nonlawyers at Work (Ann Arbor: University of Michigan Press, 1998).

44 Levin, ibid, citing Austin Sarat, "Alternatives in Dispute Processing: Litigation in a Small Claims Court" (1976) 10:3 Law \& Soc'y Rev 339 at 370; John Montague Steadman \& Richard S Rosenstein, "'Small Claims' Consumer Plaintiffs in the Philadelphia Municipal Court: An Empirical Study" (1973) 121:6 $\mathrm{U}$ Pa L Rev 1309 at 1333.

45 Levin, ibid, citing Leandra Lederman \& Warren B Hrung, "Do Attorneys Do Their Clients Justice? An Empirical Study of Lawyers' Effects on Tax Court Litigation Outcomes" (2006) 41:4 Wake Forest L Rev 1235 at 1239 .

46 Emily S Taylor Poppe \& Jeffrey J Rachlinski, "Do Lawyers Matter? The Effect of Legal Representation in Civil Disputes" (2016) 43:4 Pepp L Rev 881. 
outcomes for litigants. ${ }^{, 47}$ Finally, in her meta-analysis of dozens of existing studies, Rebecca L. Sandefur concludes that "[l]awyer-represented people are more likely to prevail than people who appear unrepresented, on average," of the presence of counsel varies widely depending on the study. ${ }^{49}$ In another article, Sandefur describes the impact of lawyers as often "spectacular when compared to ... people's attempts at self-representation." 50

Sandefur observes several patterns regarding lawyers' impact on adjudication in her metaanalysis of existing studies. First, she observes that the research suggests lawyers' potential impact on outcomes rises with the complexity of the legal proceedings. ${ }^{51}$ However, she also notes lawyers have a surprisingly large impact in non-complex proceedings where it might be expected that their impact would be less consequential. ${ }^{52}$ She speculates this result might stem from what she terms "relational expertise": the ability of lawyers to navigate various professional and interpersonal contexts of the justice system and give weight to the claims of vulnerable clients. ${ }^{53}$ This observation is echoed by Russell Engler, who attributes lawyers' impact on outcomes in litigation to their access to professional power rather than their legal expertise or procedural savvy. ${ }^{54}$

Only a small handful of American studies have undertaken controlled randomized experiments to attempt to assess lawyers' impacts on outcomes in adjudication. As noted above, the theory is that randomized control studies eliminate the possible problem of selection bias that might occur in non-randomized observational studies. James Greiner and his collaborators have conducted several methodologically rigorous randomized control trials investigating the impact of legal representation in a variety of legal contexts, including housing and unemployment insurance hearings. The Unemployment Insurance Study (the UI Study), for example, offered legal representation by clinical law students to half of the clinic's eligible unemployment insurance appeals claimants in a given time period. ${ }^{55}$ The study primarily measured two outcomes: whether the claimant was successful on appeal and the length of time it took for the appeal to conclude. ${ }^{56}$ Similarly, in the Housing Court and District Court Studies, the researchers measured the impact of offers of legal representation

\section{$47 \quad$ Ibid at 881. See also ibid at 885 .}

48 Sandefur, "The Impact of Counsel," supra note 36 at 69.

49 Ibid.

$50 \quad$ Rebecca L Sandefur, "Elements of Professional Expertise: Understanding Relational and Substantive Expertise through Lawyers' Impact" (2015) 80:5 American Sociological Rev 909 at 924 [Sandefur, "Elements of Professional Expertise"]. An example of evidence of what Sandefur might term "spectacular" impact is a recent study on the impact of counsel in immigration cases by Ingrid Eagly and Steven Shafer. The researchers examined 1.2 million deportation cases and noted that people represented by lawyers were 10.5 times more likely to win their cases as compared to detained individuals without counsel: Ingrid Eagly \& Steven Shafer, "Access to Counsel in Immigration Court" (American Immigration Council, 2016) at 1, 19, online: <https:/www.americanimmigrationcouncil.org/sites/ default/files/research/access to counsel_in_immigration court.pdf $>$. Another American study on the impact of counsel in refugee cases examined over $78,00 \overline{0}$ asylum decisions and concluded that legal representation is "the single most important factor affecting the outcome" of cases: Jaya Ramji-Nogales, Andrew I Schoenholtz \& Philip G Schrag, "Refugee Roulette: Disparities in Asylum Adjudication" (2007) 60:2 Stan L Rev 295 at 340.

Sandefur, "Elements of Professional Expertise," ibid at 921.

Ibid at 924 .

Ibid at $911-12$.

Engler, "Connecting Self-Representation," supra note 38 at 78-79.

UI Study, supra note 9.

Ibid. 
to people facing potential eviction in terms of whether an eviction occurred and, if so, how long they were able to remain on the property prior to it coming into effect. ${ }^{57}$

In contrast to the majority of previous studies, the results of Greiner and Pattanayak's UI and Housing Court Studies suggested that full representation offered in these experiments, as compared to no or limited representation, did not noticeably benefit clients. ${ }^{58} \mathrm{With}$ respect to the UI study, the authors suggest plausible explanations for this finding to include that "the claimants who initiated contact with [the clinic] possessed personal characteristics making them more likely to win their cases" compared to people who do not seek assistance or, alternatively, that the facts of their cases were unusually favourable and likely to have a positive result. ${ }^{59}$ They suggest, alternatively, that the lack of difference in outcomes between the groups may have resulted from the unemployment appeal process being one that is relatively accessible to unrepresented individuals, with judges at times adopting inquisitorial styles that potentially make it easier for unrepresented parties to communicate their case. They additionally note that the issues in first-level appeal cases tend to be relatively uncomplicated. It is possible that the unemployment appeals process is one where legal representation is less necessary, compared to other legal settings. ${ }^{60}$

In contrast, a third randomized control study by Greiner and his associates concerning representation in a District Court produced different results. ${ }^{61}$ The District Court Study had a similar design to the Housing Court Study. Again, the District Court Study randomized offers of full representation by staff lawyers from a legal service provider. Similarly, these offers were made to qualified persons facing summary eviction proceedings, this time in the district courts (as opposed to the specialized housing courts) setting. ${ }^{62}$ There was no limited same-day service provider to which participants could be referred in this study. Instead, results of clients who received offers of full representation were compared with those of people whose only assistance within the experiment was a two-to-three hour instructional clinic that involved help with completing forms. ${ }^{63}$ The data in the District Court Study showed that participants offered representation by lawyers had significantly better outcomes than those who did not receive this offer. ${ }^{64}$ For District Court Study participants who were offered legal representation, roughly two-thirds of occupants maintained possession, which was double the number who maintained possession in the control group. ${ }^{65}$ Full legal representation was clearly shown to be useful in this study.

Greiner, Pattanayak, and Hennessey discuss some potential explanations for the discrepancy between the results of their different studies. Some of these explanations relate to differing lawyering styles (the lawyers in the District Court Study adopted a more assertive approach), ${ }^{66}$ different court structure (for instance, the Housing Court setting mandated "hallway mediation" before the court hearing, which may have diminished the usefulness of

Housing Court Study, supra note 9; District Court Study, supra note 9.

Housing Court Study, ibid; UI Study, supra note 9.

UI Study, ibid at 2173.

Ibid at 2174.

District Court Study, supra note 9.

Ibid.

Ibid.

Ibid at 934.

Ibid at 908 .

Ibid at 919. 
lawyer advocacy), ${ }^{67}$ and differences between the structure of the studies (for instance, the screening decisions regarding case selection and the recruitment methods employed). It should be noted that an earlier randomized study in the housing court context, reported in 2001 by Caroll Seron and her co-authors, found that individuals facing eviction who were represented by lawyers experienced "significantly more beneficial outcomes than their counterparts who do not have legal representation. ${ }^{68}$

The Greiner and Pattanayak UI and Housing Court studies have been critiqued from a variety of angles. For example, Greiner and Pattanayak's methodology has been critiqued on the basis that it unhelpfully compares only offers of full legal representation, rather than actual representation. ${ }^{69}$ Randomization studies like those undertaken by these scholars have also been critiqued on ethical grounds; it may be inappropriate to randomly deny full representation to persons who seek out and are qualified to receive such services for the sake of research. ${ }^{70}$ Additionally, there are limitations on Greiner and Pattanayak's research since they reflect the case outcomes of only those who sought help from the relevant service providers and whose matters progressed to hearings. ${ }^{71}$

In his assessment of the impact of the Greiner and Pattanayak studies in light of the larger body of empirical research on the impacts of representation, Russell Engler concludes that the studies set out an "important exception" to the "unifying finding" in the research that lawyer representation does make a significant positive impact in outcomes of adjudication. ${ }^{72}$ He concludes that studies involving randomized control trials "make an important contribution, but do not by themselves nullify the findings of other studies using different methodologies." ${ }^{, 73}$ Additionally, Jeanne Charn has argued that a finding of no positive impact on outcomes by lawyers could in fact be celebrated as evidence that some courts or legal processes are fully accessible. ${ }^{74}$

Finally, there have been several American studies that seek to assess whether more limited scope or "unbundled" legal services, wherein lawyers provide only partial assistance or representation to a client, can be effective. There have been mixed results in the data. For example, the results of a study by Jessica K. Steinberg comparing full, unbundled, and no legal representation in the residential tenancy context showed unbundled legal services had no impact on substantive case outcomes compared to no legal representation. ${ }^{75}$ Gary Blasi found similar results in his evaluation of the effectiveness of a self-help assistance centre in the tenancy housing context. ${ }^{76}$ This study compared expressed client satisfaction and

67 Housing Court Study, supra note 9 at 11.

68 Carroll Seron, Martin Frankel \& Gregg Van Ryzin with the assistance of Jean Kovath, "The Impact of Legal Counsel on Outcomes for Poor Tenants in New York City's Housing Court: Results of a Randomized Experiment" (2001) 35:2 Law \& Soc'y Rev 419 at 420.

69 This criticism is discussed in Selbin et al, supra note 16 at 49.

70 See Steven Eppler-Epstein, "The Greiner Studies: Randomized Investigation of Legal Aid Outcomes" (2012) 46:1-2 Clearinghouse Rev J Poverty L \& Policy 43 at 45 for some discussion of this critique; see also Selbin et al, supra note 16 at 50.

See Albiston \& Sandefur, supra note 16 at 108.

Engler, "Representation," supra note 8 at 79.

Ibid at 74 .

Jeanne Charn, “Celebrating the 'Null' Finding: Evidence-Based Strategies for Improving Access to Legal Services" (2013) 122:8 Yale LJ 2206 at 2233.

Jessica K Steinberg, "In Pursuit of Justice? Case Outcomes and the Delivery of Unbundled Legal Services" (2011) 18:3 Geo J on Poverty L \& Pol'y 453.

Gary Blasi, "How Much Access? How Much Justice?" (2004) 73:3 Fordham L Rev 865 at 869. 
outcomes between those litigants who received legal advice prior to their court hearings and those who were entirely unrepresented. While there were very high rates of initial satisfaction among those who received legal services reported shortly after receiving this assistance, the self-help centre clients were less satisfied than the unassisted control group after they had gone to court. This was so notwithstanding similar objective case outcomes between the groups. $^{77}$

\section{CONSIDERATIONS FOR CANAdian RESEARCH ON THE IMPACTS OF LEGAL REPRESENTATION}

There is considerable room for Canadian research on the impacts of legal representation in legal aid and community clinic contexts. In the previous section, we canvassed the (mainly) American empirical research in this area to demonstrate the kinds of research questions and methodologies that have been employed. We have shown how the existing research tends to focus on a fairly narrow examination of the impact of lawyers on adjudication outcomes. We also note that scholars who have conducted meta-analyses and detailed reviews of the cumulative American research have concluded that lawyers providing full representation do in fact have a positive impact on the outcomes of litigation, but the significance of this impact can vary depending on context.

Future Canadian studies on the impacts of counsel on adjudicative outcomes across various contexts are therefore important and Canadian researchers may wish to replicate the methodologies and approaches of some of the studies described above. After all, case outcomes matter deeply to parties in a legal matter. For a tenant living on a limited income, for example, the outcome of not being evicted will likely be preferable to the alternative. Access to counsel for persons facing eviction will therefore likely be aimed at lessening the probability of landlords' success in these claims, thereby avoiding secondary harms associated with that outcome: tenants' potential homelessness, impacts on children, and loss of education and employment prospects.

Litigation outcome-focused research can also support calls for increased funding to legal aid programs. In a paper on New York City's project to create a right to counsel for lowincome people at risk of losing their homes, for example, Kathryn A. Sabbeth argues for the importance of case outcomes in assessing the need for and benefit of legal counsel. ${ }^{78}$ This attention to the positive case outcomes associated with people having legal representation in the housing context led to the city taking steps to secure a right to counsel in this area. ${ }^{79}$ Thus, empirically quantifiable case outcome-based data is important for demonstrating the benefit of legal services and can provide insights into further potential impacts.

However, while there is significant room for research on whether representation makes a difference in terms of case outcomes in Canadian adjudication processes, we suggest Canadian research on the impacts of legal representation should not be limited to this measure of impact. Instead, researchers should consider broader and more nuanced measures. 
These measures are likely more useful for understanding, evaluating, and improving legal services for members of marginalized communities in Canada. They additionally align more closely with metrics that communities themselves have identified as being important indicators of the impact of legal representation.

We therefore suggest that researchers emphasize community-defined metrics and attempt to design studies that reflect the definitions and justice priorities of marginalized communities. That is, researchers should start by asking: how do members of marginalized communities, to whom legal aid and community legal services are directed, understand and experience effective and impactful legal representation? Although this consideration will inevitably require specific engagement with particular communities and contexts, several Canadian studies and reports have laid some initial ground work in this area. These include the Canadian Bar Association's Access to Justice Committee report on community-informed access to justice metrics ${ }^{80}$ Paradis' review of the Tenant Duty Counsel program in Ontario, ${ }^{81}$ and Sarah Marsden and Sarah Buhler's work on lawyers and access to justice. ${ }^{82}$ In these works, members of marginalized communities speak directly about their experiences and assessments of lawyers and legal service providers. By focusing on these kinds of community-informed metrics, researchers can undertake what Albiston and Sandefur describe as the "theoretical move of redefining effectiveness more broadly." ${ }^{83}$ Below, we draw on this literature to outline considerations for research on the impacts of legal representation that go beyond immediate win or lose litigation outcomes.

\section{A . IMPACTS OF THE LAWYER-CLIENT RELATIONSHIP}

Researchers seeking to investigate the impacts of legal representation in legal aid and community legal services settings must be cognizant of the larger context in which legal aid and community legal services are provided. One notable contextual factor is the deep distrust of lawyers and the legal system that many members of marginalized communities hold. Community members may view lawyers as being associated with a system that has been a significant source of harm and injustice in their lives. This sentiment is summed up by a community participant in Marsden and Buhler's research who stated: "I think that people feel that lawyers are not on their side because they work with the justice system." ${ }^{\prime 84}$ Similarly, the CBA Justice Metrics Study documents the stress, "emotional toll," and feeling of "fight[ing] against the odds" that people navigating the legal system experience. ${ }^{85}$

For this reason, the studies referenced above emphasize the lawyer-client relationship itself as a site of impact: lawyers' attitudes and relational skills affect their clients in a myriad of ways. Marsden and Buhler conclude that humility, respect, compassion, and relationality

Amanda Dodge, "Access to Justice Metrics Informed by the Voices of Marginalized Community Members: Themes, Definitions and Recommendations Arising from Community Consultations" (Ottawa: Canadian Bar Association, 2013), online: <www.cba.org/CBA/cle/PDF/JUST13_Paper_ Dodge.pdf $>$.

$81 \quad$ Supra note 28.

82 Sarah Marsden \& Sarah Buhler, "Lawyer Competencies for Access to Justice: Two Empirical Studies" (2017) 34:2 Windsor YB Access Just 186; Sarah Buhler, “'Don't Want to Get Exposed': Law's Violence and Access to Justice" (2017) 26 J L \& Soc Pol'y 68.

Supra note 16 at 113 .

Supra note 82 at 194

Dodge, supra note 80 at 15,17 . 
are therefore key competencies for lawyers working in community-based settings. ${ }^{86}$ Paradis' focus groups with tenants navigating Ontario's housing law tribunal similarly emphasized the impact of lawyers' roles in providing both trauma-informed advice and emotional support. ${ }^{87}$ Finally, the CBA Justice Metrics Study emphasizes the importance of lawyers and legal professionals who are "fair, respectful and sensitive ... [and who] take the time to listen, to inform, and to do a good job." $" 88$

Marsden and Buhler's research suggests that researchers studying the impacts of legal representation may seek to consider whether the lawyer helped the client to feel welcome, "safe," and able to access the system, ${ }^{89}$ and to what extent representation helped the client to feel empowered..$^{90}$ The CBA Report additionally includes the concept of clients' emotional health being "considered and supported" as an access to justice metric. ${ }^{91}$ This approach is supported by Aiken and Wizner, who advocate that one measure of the effectiveness of legal services is the degree to which law students or lawyers work with clients by extending empathy, respect, and guidance. ${ }^{92}$

Of course, as the participants in the CBA Justice Metrics Study observe, lawyers must have adequate time to build relationships with clients. ${ }^{93}$ From the participants' perspective, this requires adequately funded and resourced programs. ${ }^{94}$ Research that investigates the impacts of lawyers' relationships with clients can therefore help identify practices that promote the empowerment, well-being, and knowledge of clients, and make the case for increased funding.

\section{B. IMPACTS OF INFORMAL LEGAL ADVOCACY}

As Aiken and Wizner point out, in poverty law practice settings, the majority of legal practice does not involve litigation in courts or tribunals. ${ }^{95}$ It is therefore important to investigate the impacts of legal representation outside and beyond the litigation context. Shifting the research focus to these factors makes studies more likely to fully capture and assess the impact of the varied dimensions of legal representation. In the legal aid and community legal services setting, this work by lawyers can involve activities like helping a client apply for benefits, assisting with an immigration or refugee-related application, making telephone calls to landlords to negotiate resolution of various issues, sharing information with clients about their rights in particular contexts, and referring clients to other support services. ${ }^{96}$ Informal advocacy can be "life-changing" for clients, according to Aiken and

Supra note 82 at $195-97$.

Supra note 28 at 66,68 .

Dodge, supra note 80 at 15 .

Supra note 82 at 196.

Ibid at 198. See also Dodge, supra note 80 (the CBA Justice Metrics Study noted that a metric for access to justice should be whether "[p]ower is shared equitably between justice professionals and the parties accessing justice systems" at 21).

Dodge, ibid at 18.

Supra note 7 at 83 .

Dodge, supra note 80 at $10-11$.

Ibid at $11-12$.

Supra note 7 at 84-85; the same, of course, holds true for most lawyering contexts in Canada.

See ibid for more specific examples. See also Marsden \& Buhler, supra note 82 at 196. 
Wizner. ${ }^{97}$ It is also closely connected with helping clients comprehend the system and "arrive at a reasoned assessment of fairness or lack of fairness in the system." 98

Informal legal advocacy also routinely involves assisting clients by providing legal advice and counselling and helping clients make difficult legal and non-legal choices. ${ }^{99}$ Focusing only on cases that reach hearings or litigation is a significant limitation of any study attempting to produce conclusions about the impacts or benefits of legal representation. Research should attempt to identify the impacts of the kinds of advocacy and activities identified above to create a more holistic picture.

\section{IMPACTS OF REPRESENTATION IN THE LITIGATION CONTEXT (BEYOND AdJUDiCATION OUTCOMES)}

When it comes to studying the impacts of legal representation in matters in the litigation context, a focus on adjudication outcomes is clearly only a small part of the larger picture. Multiple other measures of impact can be considered in order to provide a more holistic understanding of lawyers' impacts within litigation processes. After all, studies have shown that people are often motivated by objectives other than "rational economic concerns," and these objectives are missed by unduly focusing on case outcomes. ${ }^{100}$

One important metric is client satisfaction with both the process and the outcome. Poppe and Rachlinski note this dimension of legal representation is excluded by many existing research frameworks. ${ }^{101}$ This can include clients" perception of the "fairness" of the outcome and the process, ${ }^{102}$ the extent to which clients felt respected in the process, ${ }^{103}$ the extent to which lawyers improved clients' understanding of the legal process and outcomes, ${ }^{104}$ and, significantly, the extent to which legal representation impacted clients' dignity interests within legal processes. ${ }^{105}$ These factors are particularly important in legal aid and community legal services contexts because, as noted above, so many clients have negative experiences with legal systems and processes. This point was expressed by one of the respondents in

$97 \quad$ Supra note 7 at 84 .

98 Ibid at 84-85; see also Liz Curran, "We Can See There's a Light at the End of the Tunnel Now: Demonstrating and Ensuring Quality Service to Clients" (Canberra, Austl: Legal Aid ACT, 2012) at 5, online: <https://ssrn.com/abstract=2396964>, where Curran identified clients being "better able to understand their legal position and the options open to them" as a feature of quality legal services. Aiken \& Wizner, supra note 7 at 82

John M Conley \& William M O’Barr, "Hearing the Hidden Agenda: the Ethnographic Investigation of Procedure" (1988) 51:4 Law \& Contemp Probs 181 at 182, 184, 187, 196. See e.g. Charn \& Selbin, supra note 6 at 158; Deborah L Rhode, "Access to Justice: An Agenda for Legal Education and Research" (2013) 62:4 J Leg Educ 531 at 534. Supra note 46 at 889.

Ibid. Research by Tom Tyler has similarly shown that people care "at least as much, and often more," about perceived fairness of the process as they do about the results of the process: Tom R Tyler, "What Is Procedural Justice?: Criteria Used by Citizens to Assess the Fairness of Legal Procedures" (1988) 22:1 Law \& Soc'y Rev 103 at 128 as cited by Aiken \& Wizner, supra note 7 at 90. See also Blasi, supra note 76 , where the author recounts that clients of a housing law clinic where he worked "generally expressed satisfaction with both our representation and the legal system when we won and disappointment when we lost, depending on what we had led them to expect. Often those who lost also expressed satisfaction, provided they thought they had had a fair hearing" at 868 .

Aiken \& Wizner, supra note 7 at 90; Dodge, supra note 80.

Aiken \& Wizner, ibid.

Ibid at 98; Curran, supra note 98, likewise identified "[a] process is undergone where the client is listened to, respected and given fearless advice of their legal position" as a necessary outcome for quality legal service, at 5 . 
Buhler's Saskatoon study who said decision makers will "never hear you properly."106 Other respondents noted that many community members attempt to "avoid the system for fear of exposure to further harm to them or their families." 107 Can legal representation make a difference by mitigating the kinds of system-generated harms noted above? Can it improve the dignity and respect afforded to participants in the system? These are critical questions for researchers.

Another set of factors to consider revolves around the impact that legal representation can have on clients' time and resources. Quantifiable factors that could be measured include: the amount of time the client devoted to their legal matter; the amount of time they needed to take off from their employment, if any; the amount of money spent on their legal matter, if any (such as costs related to producing documents or arranging for childcare); and any other resources they utilized for support in the process. ${ }^{108}$ As Albiston and Sandefur have noted, representation may have effects on health costs, stress levels, and well-being of clients and the people around them. ${ }^{109}$ The monetary and other "costs" of legal problems have also been thoroughly documented by the Canadian Forum on Civil Justice's reports on everyday legal problems. ${ }^{110}$ These reports show 42.9 percent of Canadians incur monetary costs when dealing with legal problems. ${ }^{111}$ These costs are associated with lawyer fees, transportation, court filing fees, fees for use of advisors or mediators, and domestic costs including child care, among other things. ${ }^{12}$ Legal problems were also shown in the studies to correlate with negative mental and physical health impacts and other costs such as social, family, and personal costs; loss of employment; loss of housing; and access to social assistance. ${ }^{113}$ These factors are significant and worth trying to understand, and the impacts of legal representation on these other costs should be more thoroughly researched. Had analysis of these factors been incorporated into Greiner and Pattanayak's studies, we suspect the researchers would have seen differences between those who received an offer of full representation and those who did not.

\section{A MORE NUANCED AND BROADER VIEW OF "OUTCOMES"}

As noted above, there is room for Canadian research that focuses on the impacts of legal representation on outcomes in adjudication contexts. While Canadian researchers may wish to replicate the outcome-focused studies referenced earlier across a variety of legal contexts, we believe that a more nuanced and broader view of "outcomes" is also important. As

Buhler, supra note 82 at 83 ; see also Dodge, supra note 80 , throughout. Ibid at 81.

Albiston \& Sandefur, supra note 16 at 111.

Ibid.

Canadian Forum on Civil Justice, "Everyday Legal Problems and the Cost of Justice in Canada: Spending on Everyday Legal Problems" (Toronto: Canadian Forum on Civil Justice, 2018), online: $<$ cfcj-fcjc.org/wp-content/uploads/SPENDING-Everyday-Legal-Problems-and-the-Cost-of-Justice-inCanada.pdf $>$ [CFCJ, "Everyday Legal Problems: Spending"]; Canadian Forum on Civil Justice, "Everyday Legal Problems and the Cost of Justice in Canada: Income" (Toronto: Canadian Forum on Civil Justice, 2018), online: <cfcj-fcjc.org/wp-content/uploads/INCOME-Everyday-Legal-Problemsand-the-Cost-of-Justice-in-Canada.pdf $>$ [CFCJ, "Everyday Legal Problems: Income"].

CFCJ, "Everyday Legal Problems: Cost," supra note 25 at 206; CFCJ, "Everyday Legal Problems: Spending," ibid at 9; CFCJ, "Everyday Legal Problems: Income," ibid at 30.

CFCJ, "Everyday Legal Problems: Cost," ibid at 206, 208, 210; CFCJ, "Everyday Legal Problems: Spending," ibid at $10-15$.

CFCJ, "Everyday Legal Problems: Cost," ibid at 211-27. 
Albiston and Sandefur point out, a focus on case outcomes alone cannot tell us why or how legal representation matters. This is important for legal service providers. As they ask:

[D]oes representation make a difference because lawyers present the case effectively in court, because lawyers provide detailed legal information that enables clients to obtain favorable settlements in their own negotiations with the other side, or because lawyers understand how to navigate informal relationships in the court system that help produce smoother case processing and resolution? ${ }^{114}$

Given the evidence outlined above that legal representation leads to better adjudication outcomes, research may therefore seek to move toward capturing such nuanced insights about how and why this is so.

Researchers may also wish to focus on the extent to which legal representation in particular cases contributes to long-term impacts or outcomes that can be said to increase the overall stability, health, and well-being of clients. This idea echoes the argument by Deborah Rhode, who, writing about access to justice research in the American context, states that it may be valuable to investigate "long-term impacts" in order to assess the effects of legal representation. ${ }^{115}$ Rhode asks, "For example, how much does winning a landlord-tenant case help in terms of stabilizing a party's living situation or producing improvements in building conditions?"116 In a "successful" eviction or foreclosure case for a client, it may be possible to conduct follow-up and longitudinal research to determine if the client's housing situation remained secure in a period of time following the tribunal outcome. Longer term health and employment outcomes could also be measured and documented. Thus, while "winning" or "losing" a hearing may provide insights into the immediate impact of legal representation, an approach that considers longer term impacts would investigate how clients' lives are affected in the long run by adjudication outcomes. This focus would unquestionably provide a more fulsome and meaningful picture of the impacts of representation.

In addition to investigating longer term impacts experienced by individual clients, researchers may also consider the impacts of legal representation that flow to people and systems beyond the individual client. This point was made by Albiston and Sandefur, who state: "[R]epresentation can have far-reaching effects beyond the individual client."117 Sabbeth, for example, notes the presence of lawyers in particular legal settings can alter the behaviour of actors within and outside court or administrative systems. ${ }^{118}$ The presence of lawyers may shape legal precedent, deter frivolous suits, provide education to judges, embolden clients to assert their rights in the future, and prevent judges from only hearing and favouring more powerful parties. ${ }^{119}$ As Melina Buckley points out, representation in legal aid contexts may also promote long-term policy goals such as "ameliorating social inclusion or eliminating inequality." 120

$\begin{array}{ll}114 & \text { Supra note } 16 \text { at } 107 . \\ 115 & \text { Supra note } 100 \text { at } 539 . \\ 116 & \text { Ibid. } \\ 117 & \text { Supra note } 16 \text { at } 113 . \\ 118 & \text { Supra note } 28 \text { at } 88 . \\ 119 & \text { Ibid. } \\ 120 & \text { Supra note } 1 \text { at } 97 .\end{array}$


Finally, losses in court may also educate lawyers about issues in the system and lead to community mobilization and change on a broader level. The longer term impacts of losses in court are therefore also worth researching. ${ }^{121}$ Approaches that focus only on "wins" and "losses" assume, as Aiken and Wizner point out, that the legal system creates justice and is just - that is, that a "win" results in justice and a loss, in injustice. ${ }^{122}$ Indeed, Aiken and Wizner have cautioned about research that "reinforce[s] the idea that the system, functioning better through the insights we gain from our research, actually provides poor and marginalized people justice." ${ }^{23}$ A wider and longer term view of whether justice (as defined by members of marginalized communities) is achieved would provide more accurate information about impacts.

Canadian researchers may also consider investigating the impacts of legal services across different service provision contexts. As noted earlier, legal aid is delivered in different ways across provinces and a wide variety of clinic models exists across the country. Furthermore, it is important to consider whether representation by pro bono lawyers is similar or different in terms of impact as compared to service provision by staff lawyers working in a clinic context or clinical law students, for example. In the American context, Colleen Shanahan et al. recently found that clinical law students had similar impacts on case outcomes as lawyers. ${ }^{124}$ In another article, Jeanne Charn and Jeffrey Selbin describe some of the research currently being undertaken around the impact of services provided by the East Bay Community Law Center in Berkeley, California, ${ }^{125}$ and by Harvard Law School's WilmerHale Legal Services Center. ${ }^{126}$

\section{Conclusion}

In a data-starved profession under increasing scrutiny ... we can no longer rely on conviction alone. ${ }^{127}$

It should be clear from our discussion that the current data on the effectiveness and impact of legal representation is incomplete. Existing American studies on legal representation in clinical and legal aid settings focus on adjudication outcomes to determine the impact of legal services. These approaches do not always incorporate a critical understanding of justice

$121 \quad$ Ibid.

122 Supra note 7 at 95.

123 Ibid at 98-99. See generally Buhler, supra note 82.

124 Colleen F Shanahan et al, "Measuring Law School Clinics" (2018) 92:3 Tulane L Rev 547.

125 In Charn \& Selbin, supra note 6, the authors cite the following examples of prior studies assessing service interventions at East Bay Community Law Centre (EBCLC): Edward Barnes \& Liam Galbreth, "Lifting Welfare Employment Sanctions in the CalWORKs Program: The Experience of the Family Advocacy and Services Team (FAST)" (13 September 2001); Rebecca Hall, Eviction Prevention as Homelessness Prevention: The Need for Access to Legal Representation for Low Income Tenants (Berkeley Community Law Centre, 1991). Charn also describes current research being done through the EBCLC to assess the economic and dignity impacts of assisting clients with expunging their criminal records and research on clinical law issues through the Bellow Scholar Program, established by the Association of American Law Schools' Section on Clinical Legal Education: Jeanne Charn, "Foreword: The Work of the Bellow Scholars" (2012) 16:1 UDC L Rev 1 at 1-5.

126 Charn \& Selbin, ibid at 165, citing Jeanne Charn, "Preventing Foreclosure: Thinking Locally, Investing in Enforcement, Playing for Outcomes" (Paper delivered at the Fifth LSRC International Legal Services Research Conference, Cambridge University, 24-26 March 2004), online: <https://www. researchgate.net/publication/283070108_Preventing_Foreclosure_Thinking_Locally_Investing_in_ Enforcement_Playing_for_Outcomes>.

Charn \& Selbin, ibid at $1 \overline{68}$. 
or a nuanced and comprehensive appreciation of the multiple impacts of legal representation. Yet secondary and long-term outcomes and qualitative aspects of legal services matter. Empirical research must make the case that these considerations should matter to legal services funders and policy-makers. The above discussion highlights the importance of looking at a wide array of information to draw conclusions about the effectiveness and value of legal representation. Research must be approached with a broad sense of potentially relevant outcomes that can be assessed in addition to procedural and qualitative factors.

Economics often drive policy decisions and it is easier to justify a program that is not selffunded when there is empirical data to present to funders and policy-makers. As we have said above, there is room to expand the quantitative data on legal representation by measuring secondary effects of case outcomes and by measuring procedural benefits (for example, legal representation may make a client less likely to have to take time away from their employment to deal with a legal issue, or a client may receive referrals to other supports from their lawyer). These secondary effects present themselves in both substantive outcomes of a case and throughout the process of a person receiving legal advocacy from a lawyer or law student.

Public funding decisions are also sometimes made for non-economic, qualitative reasons. Selbin, Charn, Alfieri, and Wizner point out that in the medical field, efforts have been made to study patients' feelings of dignity to improve end-of-life care. ${ }^{128}$ Services in this area probably actually cost money overall but are recognised as having inherent value in which it is worth investing. There appears to be comparable support for investment in publicly funded legal service programs in Canada. In a survey done in British Columbia in 2008, respondents agreed that legal aid was important for low-income people in all areas of law. ${ }^{129}$ In the family court context, 96 percent of respondents said these services were very or somewhat important. ${ }^{130}$ Ninety-four percent said it is important in criminal court, and 93 percent and 85 percent said it was important in other civil and legal proceedings and for immigration and refugee hearings, respectively. ${ }^{131}$ The most common suggestion, when asked how legal aid services could be improved, was for funding to increase. ${ }^{132}$ Ninety-eight percent of those surveyed agreed that everyone should have the right to access the justice system, and 78 percent of people felt that legal aid should have the same funding priority as other social services, like health care, education, child protection, and welfare. ${ }^{133}$

In the Canadian context, there is insufficient empirical research on the impacts of legal representation. While this general absence of data is concerning, the lack of research assessing legal representation in the legal aid and clinical law settings is particularly problematic. Public funding of clinical and community-based service providers is precarious. It is rendered more so by the deficiency of empirical academic data demonstrating the value

Supra note 16 at 56, n 52, citing Harvey Max Chochinov et al, "The Patient Dignity Inventory: A Novel Way of Measuring Dignity-Related Distress in Palliative Care" (2008) 36:6 J Pain \& Symptom Management 559.

Ipsos Reid, "Legal Aid in BC" (Legal Services Society, 2008) at 4, online: <https://lss.bc.ca/sites/ default/files/2019-03/legalAidPollReport08.pdf>.

Ibid.

Ibid.

Ibid. Additionally, 53 percent of those surveyed said they believe legal aid services are not adequately funded.

Ibid. 
of these services. There is therefore an obvious need for data. There is also much opportunity to design research studies in Canada in a manner that is cognizant of the shortcomings of other research and the typical ways of measuring the effectiveness of legal representation, that chooses to frame research in ways that encompass a broad and community-centred view of justice, and that supplies a more accurate and complex picture of the role legal aid and community legal service providers play in increasing access to justice. In so doing, research can contribute to efforts to create justice in the lives of individuals and communities. 
[this page is intentionally blank] 